\title{
Refuge
}

Canada's Journal on Refugees

revue canadienne sur les réfugiés

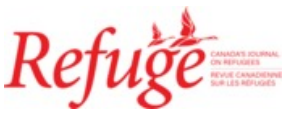

\section{Borders, Boundaries, and Exclusion in the Icelandic Asylum System}

\section{Helga Katrín Tryggvadóttir et Unnur Dís Skaptadóttir}

Volume 34, numéro 2, 2018

URI : https://id.erudit.org/iderudit/1055573ar

DOI : https://doi.org/10.7202/1055573ar

Aller au sommaire du numéro

\section{Éditeur(s)}

Centre for Refugee Studies, York University

ISSN

0229-5113 (imprimé)

1920-7336 (numérique)

Découvrir la revue

Citer cet article

Tryggvadóttir, H. \& Skaptadóttir, U. (2018). Borders, Boundaries, and Exclusion in the Icelandic Asylum System. Refuge, 34(2), 16-27.

https://doi.org/10.7202/1055573ar
Résumé de l'article

Fondé sur des théories concernant les frontières et les limites, cet article envisage de manière critique les processus par lesquels les demandeurs d'asile sont, en Islande, exclus d'une pleine participation à la société. Les lois sur l'immigration et les obstacles bureaucratiques contribuent à cette exclusion, qui résulte de restrictions en termes de participationau marché du travail, d'un manque de logements, d'une temporalité et d'un manque d'activités constructives. Nous examinons la manière dont les frontières et les limites créent l'identité du demandeur d'asile, et comment les participants à cette étude vivent cette identité. Nous déterminons par ailleurs trois domaines principaux d'exclusion : l'exclusion sociale, l'isolement et les frontières culturelles.
Copyright (c) Refuge: Canada's Journal on Refugees, 2018

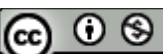

Ce document est protégé par la loi sur le droit d'auteur. L'utilisation des services d'Érudit (y compris la reproduction) est assujettie à sa politique d'utilisation que vous pouvez consulter en ligne.

https://apropos.erudit.org/fr/usagers/politique-dutilisation/ 


\title{
Borders, Boundaries, and Exclusion in the Icelandic Asylum System ${ }^{1}$
}

\author{
HELGA TRYGGVADÓTTIR AND UNNUR DÍS SKAPTADÓTTIR
}

\section{Abstract}

Grounded in theories of borders and boundaries, this article critically engages with the processes through which asylum seekers in Iceland are excluded from full participation in society. Immigration laws and bureaucratic barriers contribute to this exclusion, which is a result of restrictions on labour market participation, lack of housing, temporality, and lack of meaningful activities. We discuss how borders and boundaries create the identity of the asylum seeker and how the participants in this study experience that identity. We identify three main areas of exclusion: social exclusion, isolation, and cultural boundaries.

\section{Résumé}

Fondé sur des théories concernant les frontières et les limites, cet article envisage de manière critique les processus par lesquels les demandeurs d'asile sont, en Islande, exclus d'une pleine participation à la société. Les lois sur l'immigration et les obstacles bureaucratiques contribuent à cette exclusion, qui résulte de restrictions en termes de participation au marché du travail, d'un manque de logements, d'une temporalité et d'un manque d'activités constructives. Nous examinons la manière dont les frontières et les limites créent l'identité du demandeur d'asile, et comment les participants à cette étude vivent cette identité. Nous déterminons par ailleurs trois domaines principaux d'exclusion : lexclusion sociale, l'isolement et les frontières culturelles.

I $\mathrm{n}$ recent years increased numbers of people have claimed asylum in Iceland. After crossing multiple borders, they meet cultural boundaries and systemic barriers that they are sometimes unable to cross. These boundaries can lead to exclusion from the society in which they are trying to settle. In addition to state borders, the social and bureaucratic mechanisms that create boundaries can lead to social exclusion within states. We examine how borders and boundaries affect asylum seekers in Iceland. Asylum seekers claim a right to settle into society and they are simultaneously excluded from it. Within this context, we further investigate the interplay between national borders, cultural boundaries and social exclusion. We argue that immigration policy, bureaucracy, and social practices work as exclusionary mechanisms for asylum seekers in Iceland.

Analyzing the exclusion of asylum seekers can be problematic, since they are not generally understood to belong to the nation while their case is being processed. Their current exclusion from society is legitimated by the possibility
( ) Helga Tryggvadóttir and Unnur Dís Skaptadóttir, 2018. This open-access work is licensed under a Creative Commons Attribution-NonCommercial 4.0 International Licence, which permits use, reproduction, and distribution in any medium for non-commercial purposes, provided the original authorship is credited and the original publication in Refuge: Canada's Journal on Refugees is cited.
Cette œuvre en libre accès fait lobjet d'une licence Creative Commons Attribution-NonCommercial 4.o International License, laquelle autorise l'utilisation, la reproduction et la distribution de l'œuvre sur tout support à des fins non commerciales, pourvu que l'auteur ou les auteurs originaux soient mentionnés et que la publication originale dans Refuge: revue canadienne sur les réfugiés soit citée. 
of their future exclusion. As Cabot points out, the category of asylum seeker refers to the temporary nature of a person's relationship to a nation-state. ${ }^{2}$ Hynes has described the status of asylum seekers as one of "liminality," the state of being in between statuses. ${ }^{3}$ Yet, while maintaining this interim identity, asylum seekers live in Iceland, and they still participate in society despite these limitations on their status. As will be demonstrated in our analysis in this article, asylum seekers in our study are excluded from the normal activities of social life in Iceland. We find that this exclusion is produced through the application of immigration policy as well as through the bureaucratic practices and social norms in Iceland that create boundaries and barriers to participation in society.

In recent years, Iceland has experienced a rapid increase in the number of people claiming asylum. An island located on the periphery of Europe, Iceland has traditionally had low numbers of asylum seekers. Because of the country's location, many of the asylum seekers' cases are adjudicated through the Dublin Regulation, which allows countries to return asylum seekers to the European country to which they first arrived. Despite this likely outcome in the cases of many asylum seekers in Iceland, the waiting period for case resolution is typically long. During that period of waiting, asylum seekers are unable to fully participate in society.

This article raises the question of whether and how the asylum system in Iceland, through usage of national borders and cultural boundaries, leads to the exclusion and isolation of asylum seekers. We begin with a discussion on the theoretical background of the study, introduce the field and the methodology, and then move to the main findings. Three areas of exclusion emerged from our analysis: social exclusion, isolation, and cultural boundaries. This outcome results from restrictions on labour market participation, a reliance on social services, waiting for case resolution, and a lack of access to meaningful activities. Some asylum seekers also experience isolation related to their housing situation. We furthermore investigated the ways in which participants in this study experienced their identity as well as their experiences of racism and prejudice in Iceland. Finally, we consider their agency and resistance against the immigration system.

\section{Theoretical Overview}

Classic studies of borders and boundaries entail descriptive analysis of geographical boundaries. More recent studies of "bordering" processes increasingly focus on the human practices that represent differences between geographical spaces. ${ }^{4}$ Emphasis on borders as disappearing or becoming increasingly porous, common in the 1990 s and early 2000 , is diminishing, while more focus is put on the study of borders as securitized and militarized. They are also increasingly viewed as a dispersed or chaotic entities, performed or embodied. 5 Boundaries have been framed in different terms across disciplines, defined as a separation between spaces within geography and as a distinction between social groups within anthropology. ${ }^{6}$ In this article we focus on borders and boundaries in the anthropological sense. While borders and boundaries are generally seen as fixed, stable entities that divide up space, within political science, ${ }^{7}$ Anderson, Sharma, and Wright, view them as fundamentally ideological constructs. ${ }^{8}$ They emphasize that the effects of borders on power relations and inequality need to be investigated, as opposed to the study of borders as mere territorial boundaries that can be crossed in single events. Although the forces of globalization require and create large scale population flows, human mobility is increasingly framed within the context of problems, crisis, and threats to security. ${ }^{9}$ At the same time migration is becoming more dangerous as the result of stringent border control, which increasingly forces people to use unsafe routes and the services of smugglers. ${ }^{10}$

Traditionally within anthropology, borders and boundaries have been studied separately. Borders have been understood primarily to be territorial markers between states, whereas boundaries are seen as social constructs, establishing symbolic differences or producing identities. ${ }^{11}$ According to Fassin, the two concepts must necessarily be combined in order to understand how immigration is governed and experienced. He argues that immigrants embody the articulation of borders and boundaries: "They cross borders to settle in a new society and discover boundaries through the differential treatment to which they are submitted." ${ }^{12}$ Khosravi, moreover, claims that borders are used to expose migrants and refugees to exclusion, discrimination, and exploitation. States use borders to define who is allowed to live within their territory and who can be excluded from their territory through deportation. ${ }^{13}$ De Genova describes deportation as a means of separating what is inside from what is outside. That separation allows for the exploitation of those who are excluded from the state. By being deported or undocumented, their existence is reduced to what Agamben termed "bare life." ${ }^{4}$ Those who are "deportable" are therefore excluded from the nation and the state, even though they still live within its boundaries. ${ }^{15}$

Exclusion, furthermore, has been a subject of analysis in border studies, since the making of borders and boundaries inevitably leads to exclusion of some and inclusion of others. ${ }^{16}$ In this article, however, we focus mainly on social exclusion within Iceland while asylum seekers reside there. Studies analyzing refugee resettlement in relation to social exclusion suggest that recently resettled refugees may be vulnerable to social exclusion due to factors such as socio-economic disadvantage, lack of social support, and experiences of discrimination. ${ }^{17}$ 
The concept of social exclusion highlights mechanisms that act as barriers to full participation in society. Some individuals and groups may experience only partial social exclusion, in some aspects of social life, while those who are excluded in many ways are more vulnerable and generally experience greater difficulties. ${ }^{18}$ Social exclusion has been defined as an inability to participate in normal activities in the society in which one is geographically residing. ${ }^{19}$

\section{The Field and Background}

The borders of Iceland may seem easily defined: the country is an independent island state located in the middle of the North Atlantic Ocean. The coastline marks an obvious border between nations as well as between land and sea. It marks the outer limits of the Schengen area. Border control is strict when leaving Schengen but is less strict when moving between Iceland and other countries within Schengen. Therefore, many asylum seekers who are on their way to Canada get stuck in Iceland during border control and have few options other than to apply for asylum in Iceland. ${ }^{20}$ As the result of Iceland's location, the majority of the asylum seekers who originate outside Europe have passed through another Schengen country on the way to Iceland. The Dublin Regulation allows countries to transfer asylum seekers back to the first European country they entered. ${ }^{21}$

Historically, migration in Iceland has been on a small scale. Immigrants made up less than 2 per cent of the population in 1996. Since 2001 this proportion has steadily risen and immigrants accounted for around 9.6 per cent of the Icelandic population of just over 332,000 residents in $2016 .{ }^{22}$ Only a small proportion of immigrants are refugees. Between 1956 and 2016, 995 individuals have immigrated to Iceland as refugees or have been granted humanitarian status. Of these individuals 675 were resettled in Iceland, while 350 persons arrived as asylum seekers. ${ }^{23}$ The number of asylum seekers in Iceland has traditionally been low in comparison to neighbouring countries. The number of asylum claims was 354 in 2015 and 1,130 in 2016. ${ }^{24}$ Since 2008 , the acceptance rate of finished applications for asylum has ranged from 6 to 28 per cent. In 2016, despite a record number of accepted applications, the proportion of accepted applications was still low: just 11 per cent. ${ }^{25}$ In comparison, the acceptance rate in Norway and Sweden in 2016 was around 55 per cent. ${ }^{26}$ This difference can partly be explained by the fact that Iceland uses the Dublin Regulation more often and also by the number of asylum applicants considered to come from "safe" countries. ${ }^{27}$

According to a political scientist, Einarsson, Icelandic immigration policy follows that of the $\mathrm{EU}$ and the other Nordic countries, but within that frame, the harshest possible policy is constructed. ${ }^{28}$ Unlike Denmark, Norway, and Sweden there is a lack of clear policy on asylum seekers and refugees. ${ }^{29}$ When taking into account both geographic location and immigration laws and regulations, what appears is a strict and exclusionary immigration policy in regard to asylum seekers. As stated above, asylum seekers who arrive in Iceland are likely to have come to another European country first. The Dublin regulation allows states to send asylum seekers back to their first country of entry into Europe. The Icelandic law, ${ }^{30}$ however, states that if an asylum seeker falls under the Dublin regulation, he or she shall be sent back to the first country of entry, unless strict criteria for exceptions apply. These exceptional criteria are becoming stricter since the law was introduced in 2016, with additional regulations set by the minister of justice, allowing only very narrow room for exceptions for using the Dublin Regulation. ${ }^{31}$

If an application for asylum does not fall under the Dublin regulation, it may still be considered to be manifestly unfounded if the applicant comes from a country defined as a "safe country." 32 Additionally, an application is considered manifestly unfounded if the person does not come from a "safe country" but the application is considered to be based on economic reasons or "ridiculous" claims. 33 Whether or not an application may be considered manifestly unfounded can matter a great deal for the applicant. This is because when such application is rejected, the applicant can be deported from Iceland and forbidden to enter again for a minimum of two years and possibly permanently. Only in exceptional circumstances is he or she allowed time to leave Iceland voluntarily. 34

\section{Participants and Methods}

The discussion in this article is based on data from participant observation and interviews with eighteen men. Fifteen of the men are asylum seekers. One man is a refugee who has recently received asylum, and two of the men have received residence permits through marriage. The participants are men in their late twenties or early thirties, and they come from nine different countries. They have been away from their country of origin for different lengths of time: some for close to ten years while others left their home country less than one year prior to the study. They have also been in Iceland for various lengths of time.

The analysis is also informed by a discourse analysis of online news and comments about asylum seekers in Iceland. The participants were recruited through participation in events for asylum seekers, protests by refugee advocacy groups and meetings, as well as snowball sampling, where key informants were recruited through shared acquaintances and these informants later pointed to other participants. The participant observation was conducted through discussions and informal conversations with asylum seekers, by accompanying them to meetings with lawyers and journalists, and 
through help and consultation with bureaucratic tasks. The length of the interviews was between forty minutes and two hours. In eight of the interviews the first author was acquainted with the participant beforehand and knew some of the participant's background from informal conversations prior to conducting interviews. No data from these prior conversations were used until participants had given their consent at the time of interview. When interviews were conducted, the participants were presented with an introductory letter that explained the research and clearly stated that they were allowed to withdraw from it at any point until the publication of the results. The findings are based upon transcripts of interviews and field notes collected by the first author and thematically analyzed. In this article we will discuss the topics raised by participants indicating barriers and boundaries that they face related to participation in society.

In order to preserve the anonymity of the participants, each man's country of origin remains confidential in this analysis. This consideration is important in Iceland, where the numbers of asylum seekers are low from some countries of origin. Describing further details about the asylum seekers' identities is avoided for the same reason. Their names and other details that may reveal their identity have been changed. Ten participants are originally from the Middle East and Central Asia, seven are from Africa, and one is from Europe. Therefore the participant group is not representative of the majority of asylum seekers in Iceland in terms of country of origin, as the largest groups of asylum seekers come from Albania and Macedonia. The research findings offer a description of the situation that the study participants face. However, the findings do not allow for generalizations about refugees or asylum seekers in Iceland. The participants had different reasons for leaving their countries of origin. The majority were fleeing from conflict, murder threats, or persecution, while others talked about migrating to experience more freedom. At the time of interview, all participants under the jurisdiction of the Dublin regulation had already waited for more than six months for answers on their requests to have their cases processed in Iceland, and six of these participants had already been waiting for two to three years.

\section{Exclusion from the Labour Market}

The concept of social exclusion has been used to highlight barriers to participation in society and to analyze how social institutions systematically contribute to the exclusion of particular groups. ${ }^{35} \mathrm{~A}$ recurrent theme in the discourse on asylum seekers in Europe alludes to asylum seekers living off social benefits and being a burden on the welfare state. This discourse fails to acknowledge that asylum seekers are often denied the right to seek employment while waiting for a decision on their asylum application. ${ }^{36}$ According to Sales, the emphasis on full employment, which is a central focus in policies used to tackle social exclusion, can actually create boundaries between those who are allowed to work and those who are not. ${ }^{37}$

The participants in our study expressed a strong will to work and provide for themselves. A prominent theme in the interviews related to the participants' desires to be able to continue their lives, to study, and to start careers. Many of those who had been waiting for an answer for their asylum claim for a long time could not understand why the government would rather hand them money and free housing, instead of allowing them to work and pay taxes. For many, it was unclear whether or not they were allowed to work, and they received confusing advice from different sources. Those who did not fall under the Dublin Regulation were allowed to apply for a temporary work permit. ${ }^{8}$ These participants often found themselves in a Catch-22 situation, where a potential employer would be unwilling to offer the asylum seeker a work contract without a social security number, and the asylum seeker was not able to apply for the social security number (kennitala) without a job contract. Nyamekye explained, "I never got job, I never got job. I tried in many places. When you go to a company, the company will tell you, "Go to immigration and go and bring kennitala [social security number]." Immigration will tell you, "Go and bring contract from the company" and waiting the company will give you contract without a social security number ... Why do they tell them to go find a work when they know you are not allowed to work?"

Many of the participants who were legally allowed to apply for a temporary work permit encountered institutional and bureaucratic barriers. To apply for the permit they needed to pay over $\$ 100$ (12,000 ISK). ${ }^{39}$ After that they had to wait for an answer for up to three months, risking losing the job offer in the meantime. One participant went through this process three times and another participant endured the process five times, both without receiving any information explaining that they were not allowed to work because their application fell under the Dublin Regulation. Aref explained,

I'm not a doctor, I'm not an engineer. I'm getting like a very simple job that they can, you know, replace someone else very fast. It's matter of days or hours to get this job. And how you want me to wait for six months or three months for having kennitala? This is so stupid. So I lost three other jobs just like that. I paid 12,000, 12,000, and 12,000 . And at the end my lawyer called me: "I'm sorry but from the immigration, they told me that you cannot work." So why they took my money?

The participants described other barriers to receiving a temporary work permit. For example, some participants 
were asked to show a rental agreement or a certificate from a house owner that they already had a place to stay. $4^{\circ}$ For these participants, who had not started working to save up for rent, and who lacked social networks, that requirement proved difficult to fulfill. At the time of interview, six participants had applied for a temporary work permit after getting a job contract. Three of them had received work permits, and the other three participants were still waiting for an answer. All six of them had to wait for several months to receive their social security numbers. If the work permit was granted, it was always on a temporary basis and could be revoked if the asylum application was denied.

Those participants who did not have jobs talked about this situation taking a toll on them both mentally and socially. The consequences of not being allowed to work have been discussed elsewhere, but they include the loss of purpose, negative self-esteem, difficulties filling one's days with activities, and lack of access for integration into society. For these participants with little else to do, the lack of activity meant greater depression and increased distress. ${ }^{41}$ The participants talked about work as being important for the mental health of refugees generally. One of them explained, "These people need to work. Not because of the money or something like this. The money is also part of it. But it's kind of mental addiction, you know, the work. They need to work. They are kind of OK when they are working. When they are doing something, they are feeling that they are oK, because they don't think."

Yamin also pointed out, "Work is good to get your mind off things." Working was therefore seen as a coping strategy. From the perspective of the asylum seeker, the asylum process normally consists of one interview, and then there is just waiting for the state's decision. Therefore, temporality and waiting exemplifies the status of asylum seekers. The uncertainty of what will happen to the asylum seekers influences their whole existence. During the primary waiting period for change of immigration status, there are many smaller, but significant periods of waiting, which include waiting for lawyers, waiting for jobs, waiting for benefits, and waiting for appeals. ${ }^{42}$ As Abdou described it, "It is hard to sleep and eat, sleep and eat, so even the days feel like not twenty-four hour but fifty hours." Farid similarly said, "I have nothing to do. I really want to get my paper gone through so I can start my life. It is so boring, so tiring to just sit at home and do nothing."

Because of the lack of access to the job market, all participants had to rely on social benefits at some point, for short or long periods of time. None of them were happy about that. Adewale said, "I don't need no social service, I need a place to stay, that's what I need, that's why I left my country." Yet the majority expressed gratitude for being able to receive benefits, which some had not been able to do in other countries. When asked about the social service Jamshed said, "Everything is good. If you really have problem, if you go ask them, they will sort out your problem." Talking about the difference between being an asylum seeker in Iceland and Spain, Abdoulaye explained, "Here the way they help you if you are not working they give you food, they give you somewhere to be." They also discussed the stigma of being young and physically fit while being dependent upon social benefits. Some felt they were getting strange looks if they had to go to the social service office: "All the people are like this: they go direct to making a statement, you know, 'ok, fucking lazy'. They make decision, they make judgement very fast. And they look at you-you can read it, you don't need to ask them - they just look at you like [makes a face] ... you know what that mean: 'Lazy people, they don't work they come in and take the ... we work like a ... I'm disabled, but why are you in here?"'

Another participant mentioned that it mattered to him to wear decent clothing when he went to the social service in order to maintain his dignity.

Borders are part of the capitalist mode of production and create a "docile workforce" by giving employers power over workers. 43 People who have insecure immigration status often fear losing their job and are therefore forced to accept more difficult labour situations. Some of the participants went to great lengths to both get a job and to keep it. For example, one participant, who was living around fifty kilometres away from Reykjavík, Iceland's capital city, was not able to afford the bus ride to and from work. He took to sleeping outside in the freezing cold Icelandic winter in order to go to work the day after. Talking about the experience he said, "I went to work at ten oclock in the morning and I work until ten o'clock at night. I go out and I was walking. It was so cold, I couldn't sleep, I couldn't sleep. I walked until morning and I went to work again from ten to ten."

A few days later he got the information from the immigration office that he was not allowed to work. Another participant, who also resided outside of Reykjavík, negotiated with his employer to work at night instead of during the day for the same salary. That modification in his work schedule was the only way for him to complete his job on time in coordination with the bus schedule to his home. He was then unable to keep that job because his work permit application was pending.

Even though working may be seen as a way to diminish asylum seekers' social exclusion, their interim identity and temporary work permit does not necessarily imply inclusion within the workforce since their lack of permanent legal status hinders them from finding a permanent job. Many of the participants had been asylum seekers for five to ten years and felt that they had already missed out on the part of their lives that they should have spent educating themselves and building a career. Many believed that they were 
stuck in marginal jobs that-without the prospect of continued employment, training, or promotion-might lead to continued social exclusion. 44

\section{The Isolation of Asylum Seekers}

Schuster has argued that asylum seekers, along with undocumented migrants, are the most excluded group in society. She criticizes the practice of dispersal, which involves spreading asylum seekers geographically across many areas and not allowing them to choose where to live. ${ }^{45}$ Compulsory dispersal can be seen as one way of increasing the isolation of asylum seekers. This view is supported by Larsen, who analyzed the Danish policy of dispersing resettled refugees. Although the goal was to facilitate their integration into society, the policy in some cases increased their social isolation. ${ }^{46}$

Until 2013, asylum seekers in Iceland lived in the town of Reykjanesbær, which is located forty minutes away from Reykjavík by car. The accommodation was offered by the municipal social services. In 2013 the Icelandic state made a contract with the social service in Reykjavik as well. Since that time, asylum seekers have been housed in Reykjavík in diverse housing arrangements, from individual apartments for families, to shared apartments and accommodation centres, housing thirty to fifty asylum seekers. The biggest accommodation centres are located seven to fifteen kilometres outside the periphery of the city. 47 Of the ten participants who had been housed in accommodation centres outside Reykjavík, none said that they liked staying there. Many participants cited isolation, problems surrounding living with multiple other people, and not having much to do outside the home as reasons that contributed to these negative feelings. In that regard the people housed in smaller apartments in Reykjavík were more satisfied with their situation. Some of the accommodations are still run by the social services while others are run by the Directorate of Immigration (UTL). The houses run by the UTL have rules forbidding all visits, and at least two of them have security guards implementing those rules. Although the asylum seekers are allowed to leave their housing, the visiting ban can still increase their isolation. One participant who lived in a shared house in Reykjavík was stopped by a security guard from inviting friends over for coffee; he was told to go to a café instead. During most of the year in Iceland, it is too cold to sit comfortably outside, so meeting outside of homes often requires spending money in private establishments. Abdoulaye compared the shared house to a jail, even though they were allowed to go out: "I don't like that place either. There are too many restrictions. It is like a jail." The ban on visits can also lead to the feeling of not being completely "at home" in one's home because there is lack of full control over the space. The housing practices of the UTL might thereby be increasing the social isolation of asylum seekers.

Social isolation increases the risk of suicide and other mental health problems. Amongst asylum seekers utilizing mental health services in London, nearly half reported having positive social contact less than weekly. Even those living in shared accommodation with other asylum seekers were reported to be living in social isolation..$^{8}$ This finding coincides with the findings of Ingvarsson, Egilsson, and Skaptadóttir on asylum seekers in Iceland who did not consider other asylum seekers to be a community to which they belonged. 49 Five of the participants in our study had at some point been admitted to a psychiatric hospital. Four participants were admitted after having their applications for asylum denied in Iceland, and one was admitted before coming to Iceland. Torture and other traumatic events that asylum seekers have often experienced increase the risk of developing post-traumatic stress disorder and other mental health problems. These developments increase the risk of suicides and self-harm..$^{50}$ Bhatia describes the asylum process and the situation of asylum seekers in Britain as an ongoing trauma, where lack of sleep, housing, and food, as well as the isolation and stress of the bureaucratic process lead to self-harm and suicide attempts. "It is crucial to note that the prevalence of mental health issues amongst asylum seekers is often caused or exacerbated by the way they are treated by authorities, combined with the lack of provision for treating mental ill health." ${ }^{51}$ Worrying about family members in countries of origin also increases anxiety. Some participants in our study repeatedly described how the stress of the asylum process and waiting for resolution interfaced with their mental health struggles associated with personal experiences of traumatic events. According to them, being sent back to their homeland and executed would be preferable to their current situations: "Maybe if I stayed in [home country] I would be executed by government, but in Europe I was executed in my soul. My soul was executed. It's harder and ... you know, even I'm still with pain what happened in [home country] and also in [Dublin country]. How long can I live? I just need to rest."

The depressing situation of being an asylum seeker, with all of the waiting it entails, cannot be underestimated. While some activities are available for asylum seekers, the uncertainty surrounding their status, an ever-present fear of being deported, and their past experiences of trauma all lead to increased isolation. Many had problems sleeping, and many also talked about stress, anxiety, and depression. For example, when asked if he used the library card they were given, Yamin said, "Several times I went to library but I don't go there anymore because there is no motivation for me, no progress." Many of them also talked about having memory 
problems, as Nyamekye explained: "One is not with the brain or the fresh mind that I had before. We can talk. Me and you, we can just talk and finish. Then later when I see you outside I don't know who you are." These memory problems lead to even further isolation: "I do forget, I do forget things and sometimes it just make me ... I just feel like being alone. I don't want to talk to anybody."

Several factors create and reinforce social exclusion. Geographical isolation of asylum seekers results from living in small towns or remote areas as the result of the housing arrangements. Geographical isolation restricts access to social activities that help asylum seekers cope with their difficult situations. These activities include religious activities, prayer meetings, and other social activities held by the Red Cross.

\section{Racism, Identity and Resistance}

One boundary that immigrants face is their racialization..$^{52}$ As Fassin explains, borders and boundaries "are tightly related in a process in which immigrants are racialized." 53 Linke talks about blackness as attracting visual attention in Germany, where black bodies are "immediately seen, recognized and identified, catapulted out of the terrain of whiteness and perceived as alien, foreign and other." 54 This phenomenon can also be seen in Iceland, where black people are often seen as exotic and there is little general understanding of diversity: whiteness is understood as a normative category and part of Icelandic identity. 55

The participants who had been living outside of Reykjavík spoke about standing out in the small towns and neighbourhoods in which they lived and about feeling separated from the local residents. Most of them talked about experiencing more incidents of racism or prejudice in the smaller towns. Some of them described incidents of buses driving right past the bus stop when there were only asylum seekers waiting. Others explained that in a small town, asylum seekers are much more visible than they would be if they were to live in Reykjavík. One participant described this situation: "You are like dark spot in this white, white wall. Everybody knows you, and this is not good."

Most discussion of racism amongst the participants focused on their experiences of institutional racism. While one participant said that he had experienced no racism in Iceland, that everyone was treated equally, others talked mainly about institutional racism. When Yasim was asked if he had experienced racism in Iceland, he said, "By people, no, but by immigration, yes." Three participants said they had experienced racism many times, yet explained that they had also met a lot of good people. Most of them expressed gratitude towards Icelanders, usually explaining that they had made Icelandic friends and that many people were friendly and helpful. Some talked about Iceland being better in this regard than other European countries in which they had applied for asylum. Although many of the participants did not experience racism directly, one reason might be that racism against asylum seekers in Iceland is commonly expressed online, often in comments sections and Facebook groups. The comments are usually in Icelandic and are typically not directed at the asylum seekers themselves but instead toward other Icelanders or politicians.

Different life experiences also create boundaries between asylum seekers and Icelanders. Most of the study participants had experienced trauma in their home countries and/ or on the way to Europe. Some believed they were different from Icelanders because people born in Iceland could not comprehend these traumatic experiences: "But if you are going to see those things in your life you look like a different person, you don't look like others," said Nyamekye. One representation of this different life experience is the seemingly innocent question of "Where are you from?" For travellers in hostels or campsites this question is mostly meant as a way to establish a common ground. For refugees however, the question has different connotations and creates separation, thus constructing their identity as "others" who must constantly explain their presence. ${ }^{6}$ One participant explained, “The people here always ask me like: 'Where are you from?' I say, 'I don't have country.' 'How is possible? Where were you born?' ... You can just say, 'Yeah, this is your country' because you cannot think, you cannot imagine what is happening there to people like me."

Some of the participants were unhappy with the refugee identity and claimed that it stripped them of their rights instead of granting them rights.

Even though the system can be seen as exclusionary and isolating, asylum seekers engage in multiple strategies of resistance, 57 which include reaching out to local activists and community members, asking for legal and political assistance, starting petitions, participating in demonstrations and sit-ins, and telling their stories to the media. The participants often referenced their human rights. They explained that they should be allowed access if Europe in general, or Iceland in particular, was committed to upholding human rights. They also referred to their disillusionment in how the European system worked: "I don't beg them. I don't beg nobody and ... to give me place and ... you know. 'Oh please give me place.' No. According to human right you have to. If you sign, you respect for human right. Also you have to do not on paper ... just sign, act, action, but [otherwise it is] ... just slogan."

\section{Discussion}

As Anderson, Sharma, and Wright point out, borders are an ideological construct and instead of asking what is a border, they point out that we should ask where, who, and what 
constitutes a border, underlining the temporality, territoriality, and subjectivity of borders. Borders are therefore experienced in myriad ways by different people, from "registered travellers" to irregular border crossers..$^{58}$ Asylum seekers inhabit a space at the border. Although they are geographically present within a territory of the state, their status is somewhere between resident and alien. Khosravi discusses who is the border in the context of Agamben's term of "inclusive exclusion," where undocumented migrants and asylum seekers are positioned at the "threshold of in and out" where their existence is "indistinct from the border." 59 They are therefore neither fully included nor fully excluded: "Hence the undesirable persons are not expelled by the border, they are forced to be border." ${ }^{60}$ Fassin similarly speaks of immigrants as embodying the articulation of borders and boundaries. ${ }^{61}$ The idea of who is the border can also be discussed in terms of Butler's idea of "petty sovereigns": bureaucrats who perform sovereign power. ${ }^{62}$

So who is the border? Is the border the asylum seeker who embodies the border? Or is the border the bureaucrat who creates and maintains these power relations by doing the "dirty work of selecting the good immigrants from the bad ones?"63 Borders are an exclusionary mechanism in their function of defining who belongs to the state. Borders are therefore, by their very nature, "a tool of exclusion." ${ }^{4}$ In that sense, borders are also used for building a community within the nation-state and as a means of defining the nation. According to Aas, border surveillance is not meant just as an externally directed exclusion but also for "internal community building, integration and governance." 65 Bosworth points out that a sharp distinction is made in the United Kingdom between deserving and undeserving migrants. By stating who may enter and how long they may stay, the state differentiates the centre from the margin and distinguishes the citizens from the non-citizen. ${ }^{66}$ The state therefore fabricates a vision of national identity, based on exclusion. This practice of deciding who is accepted or excluded raises questions of eligibility: who can belong to the nation, and how that is decided. In this sense, borders are a vital part of forming and defining a nation.

Boundaries share with borders the function of exclusion, since they are social constructs that are based on symbolic differences, whether they are class, gender, race, or other identities. ${ }^{67}$ By creating identities of those who belong to these groups, boundaries also create the identity of those who do not belong to them. The idea of racialized boundaries suggests that boundaries between immigrants and other inhabitants in Western nations are formed on the basis of a contrast between those who are visually black, and the majority population whose whiteness is seen as the norm. ${ }^{68}$ Social boundaries can therefore be racial, but boundaries are formed according to how "we" are created in distinction to "them." 69 This might be seen as one reason why some participants in this study are reluctant to take up the refugee identity, because they want to belong to the majority population rather than being singled out as a different group. As the participants themselves pointed out, the different legal status of asylum seekers in comparison with residents, different life experiences, and the identity of the refugee create a boundary between them and other residents of Iceland. This is in accord with Brown's critique of the identity category of refugee, precisely because of the exclusionary character of identity categories. $7^{0}$

Both Anderson and Griffiths have pointed out that time remains under-theorized in relation to migration and that exclusion in relation to migration can also be temporal. ${ }^{71}$ Griffiths describes how irregular migrants have to suffer from both imminent and absent change, both being subject to deportation orders and the inability to change their situation. She describes how time, which is considered to be a limited resource by people participating in capitalist production, becomes not abundant but oppressive, because of the anxiety felt by asylum seekers and deportable migrants. The temporality of their situation colours their existence, both in terms of waiting for long periods and in "frenzied time" when they face negative decisions and have a short time to file appeals or contest the orders. ${ }^{72}$ Bourdieu defines absolute power as the power to make oneself unpredictable and place other people in total uncertainty: "The all-powerful is he who does not wait but who makes others wait."73 In this view, the power relations between asylum seekers and the state can be understood as the relationship between the all-powerful and the powerless, where the state can make asylum seekers wait for years or deport them with short notice. However, as Khosravi notes, "Waiting can be an act too, a strategy of defiance by the migrants." 74 Filing appeals, for example, prolongs their wait, but it might lead to positive results. Therefore, many asylum seekers are prone to not give up hope, even if it entails more waiting.

Because of asylum seekers' in-betweenness and the temporality of their situation, they are faced with barriers that hinder their full participation in society and increase their exclusion from it. ${ }^{75}$ In this article we have identified several barriers that can lead to the social exclusion of asylum seekers. European welfare states put great emphasis on full economic participation and, as Sales has pointed out, paid employment is seen as a path to social inclusion..$^{6}$ Therefore barriers to participation in the labour market serve not only serve as economic disadvantages but also as exclusionary mechanisms. The ultimate exclusion of persons in this world must be the exclusion from rights, as Arendt discussed in her famous works. Since only national states have the power 
to implement human rights, they are therefore confined to national citizens. ${ }^{77}$ The participants often referenced their human rights as a reason $\mathrm{f}$ their refugee status should be accepted. They resisted their negative answers or deportation orders on the grounds that these decisions violated their human rights. ${ }^{78}$ Borders are a space of exclusion and transgression, but also of resistance. However, resistance can be indicative of both inclusion and exclusion, since many asylum seekers want to be cooperative in order to be allowed to settle in Iceland, the goal therefore being inclusion within the state. 79

\section{Conclusion}

We have discussed the multiple ways in which borders and boundaries are created and maintained daily and how the participants in this study experience them. We have shown how many aspects of the asylum system create barriers to full participation in society and how that leads to social exclusion. When asylum seekers come to Iceland, many boundaries hinder their participation in society. Employment has often been seen as a means to tackle social exclusion, but asylum seekers who experience barriers to employment are rarely able to use it to be included. The participants in this study all expressed will to work and participate in society, although most encountered structural barriers to that goal. Not being able to work took a mental toll on them and increased their isolation. The participants not only saw employment as a means to survive or a way to a better life, but also as a way to relieve anxiety and let time pass. The participants who managed to get a temporary work permit while they were still waiting for an answer in their asylum case had a very insecure employment status, since their work permit could be revoked if their asylum claim was rejected. Most participants depended on social housing, which acted as a barrier to employment, since having their own home was a requirement to receive a work permit. Then again, renting an apartment was difficult without a job. That led them to depend on the social service, which, instead of creating a common identity with other people in the same position, reinforced their exclusion from society because they were young and able-bodied.

Social isolation is a risk factor for suicide and self-harm. Asylum seekers are often seen as a homogenous group that ought to be able to socialize among themselves. However, not all asylum seekers feel they belong to a community based on their shared experience. Many would prefer to socialize as a part of the wider society. Some of their social isolation is due to them wanting to be alone, as a result of their difficult situation and traumatic past, which make them want to isolate themselves even further. In that way, different life experiences also contribute to isolation and exclusion.
The participants experienced racialization, particularly in the smaller residential communities. The boundaries were also based upon their identity as asylum seekers, which many of the participants thought was a negative stamp. The legal status of asylum seekers contributes to their exclusion and isolation from society. Waiting is a crucial aspect of being an asylum seeker, and in many ways their existence is defined by it. The waiting to which they are subject also underscores their powerlessness vis-à-vis the bureaucratic system and increases their isolation. Although many of the participants had felt hopeless at some point, they still showed methods of resistance and ways of coping with their situation.

The boundary between the asylum seekers and Icelanders is due to these different factors: not being able to work, living off government benefits, and just waiting. The borders that asylum seekers face are not only the very real borders they have already crossed on boats, walking through deserts and forests, or by climbing walls and mountains; they are also met with boundaries daily that are result from the colour of their skin, different life experiences, and their identities imposed upon them and/or accepted by them. Boundaries are also constructed by factors such as not blending in and result directly from identification as a refugee or asylum seeker instead of just being a person.

\section{Notes}

1 This study is part of Mobilities and Transnational Iceland, a project of excellence funded by Rannís, the Icelandic Centre for Research.

2 Heath Cabot, "Governance of Things: Documenting Limbo in the Greek Asylum Procedure," PoLAR: Political and Legal Anthropology Review 35, no. 1 (2012): 11-29.

3 Patricia Hynes, The Dispersal and Social Exclusion of Asylum Seekers: Between Liminality and Belonging (Bristol: Policy, 2011), 2.

4 Henk Van Houtum, "The Geopolitics of Borders and Boundaries," Geopolitics 10, no. 4 (2005): 672-79; David Newman, "The Lines That Continue to Separate Us: Borders in Our 'Borderless' World," Progress in Human Geography 30, no. 2 (2006): 143-61; Maribel Casas-Cortes, Sebastian Cobarrubias, Nicholas De Genova, Glenda Garelli, Giorgio Grappi, and Charles Heller, "New Keywords: Migration and Borders," Cultural Studies 29, no. 1 (2015): 55-87.

5 Alison Mountz, Seeking Asylum: Human Smuggling and Bureaucracy at the Border (Minneapolis: University of Minnesota Press, 2010); Corey Johnson, Reece Jones, Anssi Paasi, Louise Amoore, Alison Mountz, Mark Salter, and Chris Rumford, "Interventions on Rethinking 'the Border' in Border Studies." Political Geography 30, no. 2 (2011): 61-9; Shahram Khosravi, "The Illegal Traveller: An AutoEthnography of Borders," Social Anthropology/Anthropologie Sociale 15, no. 3 (2007): 321-34. 
6 Van Houtum, "Geopolitics of Borders and Boundaries."

7 Anssi Paasi, "Boundaries as Social Processes: Territoriality in the World of Flows," Geopolitics 3, no. 1 (1998): 69-88.

8 Bridget Anderson, Nandita Sharma, and Cynthia Wright, "Editorial: Why No Borders?" Refuge 26, no. 2 (2009): 5-18.

9 Mary Bosworth, "Border Control and the Limits of the Sovereign State," Social and Legal Studies 17, no. 2 (2008): 199-215.

10 Ruben Andersson, Illegality Inc.: Clandestine Migration and the Business of Bordering Europe (Oakland: University of California Press, 2014); Shahram Khosravi, Is a World without Borders Utopian? (Stockholm: Silent University, 2013).

11 Didier Fassin, "Policing Borders, Producing Boundaries: The Governmentality of Immigration in Dark Times," Annual Review of Anthropology 40, (2011): 213-26.

12 Fassin, "Policing Borders, Producing Boundaries, 215.

13 Khosravi, Is a World without Borders Utopian?

14 Giorgio Agamben, Homo Sacer: Sovereign Power and Bare Life (Stanford: Stanford University Press, 1998).

15 Nicholas De Genova, "The Deportation Regime: Sovereignty, Space, and the Freedom of Movement," in The Deportation Regime: Sovereignty, Space, and the Freedom of Movement, ed. Nicholas De Genova and Nathalie Putz (Durham, nc: Duke University Press, 2010).

16 Katja Franko Aas, “Crimmigrant' Bodies and Bona Fide Travelers: Surveillance, Citizenship and Global Governance," Theoretical Criminology 15, no. 3 (2011): 335 .

17 Ignacio Correa-Velez, Ramon Spaaij, and Susan Upham, "We Are Not Here to Claim Better Services Than Any Other': Social Exclusion among Men from Refugee Backgrounds in Urban and Regional Australia," Journal of Refugee Studies 26, no. 2 (2012): 163-86.

18 Correa-Velez, Spaaij, and Upham, "We Are Not Here to Claim Better Services."

19 Tania Burchardt, Julian Le Grand, and David Piachaud, "Social Exclusion in Britain 1991-1995," Social Policy and Administration 33, no. 3 (1999): 229.

20 Lilja Ingvarsson, Snæfríður Póra Egilsson, and Unnur Dís Skaptadóttir, "I Want a Normal Life Like Anyone Else': Daily Life of Asylum Seekers in Iceland," Scandinavian Journal of Occupational Therapy 23 (2016): 416-24, doi.org/ 10.3109/11038128.2016.1144787.

21 In short, the Dublin Regulation (Dublin III) refers to an agreement between EU states, which means that the first country in which a person submits an asylum application should be responsible for the asylum claim. See European Commission, "Country Responsible for Asylum Application (Dublin)," 7 April 2017, https: //ec.europa.eu/home-affairs/ what-we-do/policies/asylum/examination-of-applicants_ en. If people's fingerprints are found in the EURODAC database, it is possible to resend those people to the first country they came to in Europe. See European Commission, "Identification of applicants (EURODAC)," 30 March 2017, https: //ec.europa.eu/home-affairs/what-we-do/policies/asylum/ identification-of-applicants_en.
22 For Icelandic population statistics: Statistics Iceland, "Inhabitants Overview," 26 February 2017, http: //www.statice.is/statistics/population/inhabitants/overview/; Statistics Iceland, "Background," 26 February 2017, http: //www. statice.is/statistics/population/inhabitants/background/.

23 For statistics on resettled refugees, see Ministry of Welfare, "Koma flóttamanna frá 1956," 28 February 2017, https: //www.velferdarraduneyti.is/malaflokkar/flottafolk/mottaka/nr/1228. For more information on conclusion of asylum cases, see Directorate of Immigration, "Conclusions of Decided Cases by Nationality in 2016," 28 February 2017, http: //utl.is/files/Asylum_statistics_2016.pdf.

24 Directorate of Immigration, "Ársskýrslur," 20 February 2017, http: //utl.is/index.php/um-utlendingastofnun/arsskyrslur.

25 Directorate of Immigration, "Ársskýrslur."

26 See the Swedish Directorate of Immigration; Migrationsverket, "Statistics for 2015," 20 February 2017, https:// www.migrationsverket.se/English/About-the-Migration-Agency/Statistics/Asylum.html; and the Norwegian Directorate of Immigration; UDI, "Asylum Decisions by Citizenship and Outcome (2016)," 20 February 2017, https: //www.udi.no/en/statistics-and-analysis/statistics/ asylum-decisions-by-citizenship-and-outcome-2016/.

27 Directorate of Immigration, “Tölfrææi hælismála," 20 February 2017, http: //utl.is/index.php/um-utlendingastofnun/ toelfraedhi.

28 Eiríkur Bergmann Einarsson, "Íslenskt pjóðerni og óttinn við innflytjendur," Ritið 2-3 (2007): 57-78.

29 Alpjóðamálastofnun Háskóla Íslands, "Greining á pjónustu við flóttafólk," 27 February 2017, http://ams.hi.is/wp-content/uploads/2017/o2/Flottamannaskyrsla2017.pdf.

30 Act on Foreigners, Icelandic law 80/2016, c 36. http://www. althingi.is/lagas/148a/2016o8o.html.

31 Regulations Amending the Act on Foreigners, Icelandic Law 540/2017, c 43; 775/2017 and 276/2018. https://www. reglugerd.is/reglugerdir/eftir-raduneytum/dmr/nr/20605.

32 Act on Foreigners, 80/2016, c 29.

33 Regulations, 775/2017, c 45, s X.

34 Regulations, 540/2017, c 43 and 775/2017, c 49.

35 Correa-Velez, Spaaij, and Upham, "We Are Not Here to Claim Better Services," 165.

36 Mark Duffield, "Racism, Migration and Development: The Foundations of a Planetary Order," Progress in Development Studies 6, no. 1 (2006): 68-79.

37 Rosemary Sales, "The Deserving and the Undeserving? Refugees, Asylum Seekers and Welfare in Britain," Critical Social Policy, 22 no. 3 (2002): 459.

38 Directorate of Immigration, "Bráðabirgðadvalar- og atvinnuleyfi hælisleitenda," 20 February 2017, http: //utl.is/index. php/rettindi-og-thjonusta-vidh-haelisleitendur.

39 Directorate of Immigration, "Bráðabirgðadvalar- og atvinnuleyfi hælisleitenda."

40 Directorate of Immigration, "Bráðabirgðadvalar- og atvinnuleyfi hælisleitenda." 
41 Lisa Doyle, "I Hate Being Idle": Wasted Skills and Enforced Dependence among Zimbabwean Asylum Seekers in the UK (London: Refugee Council, 2009); Lisa Hartley and Caroline Fleay, Policy as Punishment: Asylum Seekers in the Community without the Right to Work (Perth: Curtin University, 2014); Ingvarsson, Egilsson, and Skaptadóttir, "I Want a Normal Life."

42 Shahram Khosravi, "Waiting," in Migration: The COMPAS Anthology, ed. Bridget Anderson and Michael Keith (Oxford: COMPAs, 2014), 74-5.

43 Khosravi, Is a World without Borders Utopian?; Anderson, Sharma, and Wright, "Editorial: Why No Borders?"

44 A.B. Atkinson, "Social Exclusion, Poverty and Unemployment," in Exclusion, Employment and Opportunity, ed. A.B. Atkinson and John Hills, 1-20 (London: Centre for Analysis of Social Exclusion, 1998).

45 Liza Schuster, The Exclusion of Asylum Seekers in Europe (Oxford: COMPAs, 2004).

46 Birgitte Romme Larsen, "Becoming Part of Welfare Scandinavia: Integration through the Spatial Dispersal of Newly Arrived Refugees in Denmark," Journal of Ethnic and Migration Studies 37, no. 2 (2011): 333-50.

47 The two big asylum centres run by the Directorate of Immigration are both in remote locations: one is around fifteen kilometres from the closest town, and another is located seven kilometres outside the same town. Buses run only twice a day to the nearest stop, otherwise it takes about one hour to walk. The asylum seekers living in these locations therefore have difficulties going outside their home. See Rúv, "Víðines: Heilbrigðiseftirlit gagnrýnir aðbúnað,” 27 March 2017, http://www.ruv.is/ frett/vidines-heilbrigdiseftirlit-gagnrynir-adbunad; and vísir, "Rauði krossinn gagnrýndi staðsetningu Arnarholts," 17 March 2016, http://www.visir.is/g/2016160318814/ raudi-krossinn-gagnryndi-stadsetningu-arnarholts.

48 Juliet Cohen, "Safe in Our Hands? A Study of Suicide and Self-Harm in Asylum Seekers," Journal of Forensic and Legal Medicine 15 (2008): 235-44; Helen McColl and Sonia Johnson, "Characteristics and Needs of Asylum Seekers and Refugees in Contact with London Community Mental Health Teams," Social Psychiatry and Psychiatric Epidemiology 41 (2006): 789-95.

49 Ingvarsson, Egilsson, and Skaptadóttir, "I Want a Normal Life."

50 Cohen, "Safe in Our Hands?"

51 Monish Bhatia, “Turning Asylum Seekers into 'Dangerous Criminals': Experiences of the Criminal Justice System of Those Seeking Sanctuary," International Journal for Crime, Justice and Social Democracy 4, no. 3 (2015): 102.

52 Fassin, "Policing Borders," 213.

53 Fassin, "Policing Borders."
54 Uli Linke, "Fortress Europe: Globalization, Militarisation and the Policing of Interior Borderlands," Topia 23-4 (2008): 113 .

55 Kristín Loftsdóttir, "Negotiating White Icelandic Identity: Multiculturalism and Colonial Identity Formations," Social Identities 17, no. 1 (2011): 11-25; Kristín Loftsdóttir, "Still a Lot of Staring and Curiosity': Racism and Racialization of African Immigrants in Iceland," in New Dimensions of Diversity in Nordic Culture and Society, ed. Jenny Björklund and Ursula Lindqvist, 263-78 (Newcastle upon Tyne: Cambridge Scholars Publishing, 2016).

56 Heath Cabot and Ramona Lenz, "Borders of (In)visibility in the Greek Aegean," in Culture and Society in Tourism Contexts, Tourism Social Science Series, 17, ed. A.M. Nogués-Pedregal, 159-79 (Bingley: Emerald Group Publishing, 2012).

57 Heath Cabot, "The Social Aesthetics of Eligibility: NGo Aid and Indeterminacy in the Greek Asylum Process," American Ethnologist 40, no. 3 (2013): 452-66.

58 Aas, “Crimmigrant' Bodies."

59 Khosravi, "Illegal Traveller, 332.

60 Khosravi, "Illegal Traveller," 333.

61 Fassin, "Policing Borders," 214.

62 Judith Butler, Precarious Life: The Powers of Mourning and Violence. (London: Verso 2004).

63 Fassin, "Policing Borders," 218.

64 Aas, “Crimmigrant' Bodies," 332.

65 Aas, “Crimmigrant' Bodies," 334.

66 Bosworth, "Border Control."

67 Fassin, "Policing Borders," 214.

68 Fassin, "Policing Borders"; Loftsdóttir, "Negotiating White Icelandic Identity."

69 Michèle Lamont and Nicolas Duvoux, "How Neo-Liberalism Has Transformed France's Symbolic Boundaries?" French Politics, Culture and Society 32, no. 2 (2014): 57-166; Michèle Lamont and Virág Molnár, "The Study of Boundaries in the Social Sciences," Annual Review of Sociology 28 (2002): 167-95.

70 See discussion on Wendy Brown's work in Jennifer Hyndman and Wenona Giles, "Waiting for What? The Feminization of Asylum in Protracted Situations," Gender, Place and Culture 18, no. 3 (2011): 361-79.

71 Ruben Andersson, "Time and the Migrant Other: European Border Controls and the Temporal Economics of Illegality, American Anthropologist 116, no. 4 (2014): 1-15; Melanie B.E. Griffiths, "Out of Time: The Temporal Uncertainties of Refused Asylum Seekers and Immigration Detainees," Journal of Ethnic and Migration Studies 40, no. 12 (2014): 1991-2009.

72 Griffiths, "Out of Time."

73 Pierre Bourdieu, Pascalian Meditations (Stanford: Stanford University Press, 2000), 228.

74 Khosravi, "Waiting," 74. 
75 Correa-Velez, Spaaij, and Upham, "We Are Not Here to Claim Better Services."

76 Sales, “The Deserving and the Undeserving?"

77 Hannah Arendt, The Origins of Totalitarianism (San Diego: Harcourt Brace, 1973).

78 Arendt, Origins of Totalitarianism.

79 Patricia Owens, "Reclaiming 'Bare Life'? Against Agamben on Refugees." International Relations 23, no. 4 (2009): 579.
Helga Tryggvadóttir was a PhD researcher at the University of Iceland before her unfortunate and untimely death. The Refuge editorial team expresses our sincere condolences to Helga's family, friends, and colleagues.

Unnur Dís Skaptadóttir is a professor in the Faculty of Social and Human Sciences at the University of Iceland. The author maybecontacted atunnurd@hi.is. 